\title{
TRANSATLANTIC TRADE AND INVESTMENT PARTNERSHIP (TTIP) - THE POSSIBLE IMPACT ON THE EUROPEAN UNION AND NORTH AMERICA
}

\author{
Nicole Wassenberg ${ }^{1 *}$ \\ ${ }^{* 1}$ MBA University: University of West Hungary, Sopron, Country: Hungary
}

*Corresponding Author: -

\begin{abstract}
: -
The Transatlantic Trade and Investment Partnership (TTIP) is projected high-standard and inclusive free trade agreement which is being conversed between the United States (US) and European Union (EU). Transatlantic Trade and Investment Partnership is a chain of trade negotiations operating between EU and US. The TTIP is mainly about decreasing the regulatory obstacles to trade to open up a way for bigger businesses such as environmental legislation, food safety, sovereign powers of the individual nations and also banking regulations. The US and EU are two of the most integrated countries when it comes to economy globally. It is as a result of their trade in services, investments and the high commercial presence in each other's financial prudence. These two regions support each other when it comes to the economy, and that's why they are good trading partners in products and services. The EU and U.S trade and investment partnership which is sometimes referred to as transatlantic economy has a significant global relationship and creates a mutually beneficial understanding between the two states (Hoekman and Kostecki, 2009). The TTIP is one of the largest trade and investment partnership in the world and also the most significant because of its absolute size. It has many for example the European Union has 28 member states which include: Bulgaria, Cyprus, Belgium, Austria, Czech Republic, Estonia, Germany, Denmark, Finland. Greece, Ireland, Hungary, Italy,

Netherlands, Poland, Slovenia, Lithuania, Romania, Spain, Latvia, Sweden, Portugal and United Kingdom are also part of the partnership. The initial negotiations on TTIP which was to become the first largest bilateral free trade and investment partnership agreement were earlier supported by a paramount and independent study of the Center for Economic Policy Research (CEPR). The study by CEPR was called Reduction of the Transatlantic Barriers to Trade and investment. The negotiations were mainly to provide independent advice to the two negotiators based on the additional research. Despite, TTIP being one of the largest trade and investment partnership, it has created both negative and positive impacts on the two states. There are benefits $t$ being enjoyed by the member states such as job creation and home growth. The EU depends on the US exports; they can get investments from the US and also import the goods and services they require (Khanna, Palepu, and Sinha, 2005). Other positive impacts of the TTIP includes; upholding and promoting human rights, governing in a transparent manner that can hold to account individuals in authority and also has markets that can be open to free and reasonable competition and is well-regulated market areas. TTIP also protects the people and the planet through their international rules. For example, the rules look at everyone's health, their condition at workplaces, the endangered species around them and the entire environment. There are also challenges that have come out from TTIP in the field of politics and economics, poor labor standards, workers' rights and security of their workplaces, democracy, and state authority. Foreign shareholder protection, public health and the environment as a whole, health care, consumer safety and food security, climate change and environment protection, banking regulation and privacy and many others. Some competitors challenge the TTIP on slowness in services than in goods leading to difficulty in opening markets in service areas.
\end{abstract}

Keywords: - Transatlantic, Trade, Investment, Partnership, (TTIP), possible, impact, on, European, Union, North America

\section{() $\circledast$ (1)}

Distributed under Creative Commons CC BY-NC 4.0 OPEN ACCESS 


\section{INTRODUCTION}

The Transatlantic Trade and Investment Partnership (TTIP) is projected high-standard and inclusive free trade agreement which is being conversed between the United States (US) and European Union (EU). Transatlantic Trade and Investment Partnership is a chain of trade negotiations operating between EU and US. The TTIP is mainly about decreasing the regulatory obstacles to trade to open up a way for bigger businesses such as environmental legislation, food safety, sovereign powers of the individual nations and also banking regulations. The US and EU are two of the most integrated countries when it comes to economy globally. It is as a result of their trade in services, investments and the high commercial presence in each other's financial prudence. These two regions support each other when it comes to the economy, and that's why they are good trading partners in products and services. The EU and U.S trade and investment partnership which is sometimes referred to as transatlantic economy has a significant global relationship and creates a mutually beneficial understanding between the two states (Hoekman and Kostecki, 2009).

The TTIP is one of the largest trade and investment partnership in the world and also the most significant because of its absolute size. It has many for example the European Union has 28 member states which include: Bulgaria, Cyprus, Belgium, Austria, Czech Republic, Estonia, Germany, Denmark, Finland. Greece, Ireland, Hungary, Italy, Netherlands, Poland, Slovenia, Lithuania, Romania, Spain, Latvia, Sweden, Portugal and United Kingdom are also part of the partnership. The initial negotiations on TTIP which was to become the first largest bilateral free trade and investment partnership agreement were earlier supported by a paramount and independent study of the Center for Economic Policy Research (CEPR). The study by CEPR was called Reduction of the Transatlantic Barriers to Trade and investment. The negotiations were mainly to provide independent advice to the two negotiators based on the additional research. Despite, TTIP being one of the largest trade and investment partnership, it has created both negative and positive impacts on the two states. There are benefits t being enjoyed by the member states such as job creation and home growth. The EU depends on the US exports; they can get investments from the US and also import the goods and services they require (Khanna, Palepu, and Sinha, 2005). Other positive impacts of the TTIP includes; upholding and promoting human rights, governing in a transparent manner that can hold to account individuals in authority and also has markets that can be open to free and reasonable competition and is well-regulated market areas. TTIP also protects the people and the planet through their international rules. For example, the rules look at everyone's health, their condition at workplaces, the endangered species around them and the entire environment.

There are also challenges that have come out from TTIP in the field of politics and economics, poor labor standards, workers' rights and security of their workplaces, democracy, and state authority. Foreign shareholder protection, public health and the environment as a whole, health care, consumer safety and food security, climate change and environment protection, banking regulation and privacy and many others. Some competitors challenge the TTIP on slowness in services than in goods leading to difficulty in opening markets in service areas.

\section{Development of TTIP and its historical background}

TTIP was first announced in the 1990s and was proposed by a German Chancellor after the fall of Doha world trade negotiation in 2006. The European Union and the United States agreed to sign a Declaration, which enabled the continuation North Atlantic Treaty Association (NATA) (Smith, 2013). The agreement created also has paved ways for the annual summits, biannual consultations among the ministers of states and led to more frequent meetings between the political figures and the high-ranking officials. Different initiatives were taken by the United States government and the EU Commission and they include:

1. Creation of pressure groups of corporate individuals known as the Transatlantic Business Dialogue by authorities from two sides of Atlantic in 1995.

2. The creation of an advisory committee for the Transatlantic Economic Partnership in 1998.

3. Formation of TTIP Economic Council consisting representatives from US and EU to advise the two states, 2007.

4. Formation of a High -level group of authorities who made recommendations on the launching of negotiations for some time on the free-trade contract, 2011.

The TTIP agreements were opened on the month of July, 2013. It was opened by the EU and US leaders mainly to help them accomplish a further opening up of the two economies. The main aim of the negotiation was to loosen trade further and encourage investment between EU and US through establishing an inclusive free trade agreement. The TTIP is under continuing negotiations with three main broad areas: Specific regulation and more general rules, market access, and doctrines and ways of co-operation (Cottier, 2006). The negotiations were scheduled to last until 2014 but to some economists, the negotiations are believed to extend up to 2019 or 2020 . The contents concerning the mentioned proposals as well as the reports from the discussions came from public classification, which changed after one of the proposed draft leaked in 2014.

Due to the leakage of March 2014, the EU announced a public discussion on the inadequate sectors and in the month of January 2015, the Commission upgraded security on their secrecy and distributed different parts of the outline. In some circumstances, TTIP is said to have been started on unpleasant note since it was launched in the middle of an explosive cocktail scandal which was full of unspecified grand motivations, too many secrets, unclearly defined concepts, and totally impractical deadlines. It was the time when both the two states were trying to show how difficult it is to assemble all the necessary partnerships for such an attempt. This act made it hard for the transatlantic trade and investment partnership stand firm and be open with each and every step they conclude on during negotiation (Alter and Meunier, 2006). The 
United States and the European Union have conducted three important rounds of talks since it was launched. The rounds were managed by the European Union Commission and the office of the US trade representative to safeguard the success of the promises. The first round of negotiation was conducted on July $8^{\text {th }}, 2012$ and 2013 in Washington DC where exploration of important issues was supposed to be addressed in an inclusive negotiation and identification of areas of emergency and deviation noted. Another round of consultation was carried out from $11^{\text {th }}$ to

$15^{\text {th }}$ November 2013 in Brussels, and there was an essential commitment than the first round (Abrahamson and City, 2008). In this session, the examination of individual approaches to precise trade and investments issues were discussed. Potential meeting in areas such as facilities, reserves, regulatory issues concerning energy and raw materials were also put into consideration.

The third and the last round since the launch of TTIP were conducted from $16^{\text {th }}$ to $20^{\text {th }}$ December 2013 in Washington DC. This series mainly looked at the Identification of zones of convergence and divergence in tactics that can lead to an agreement basing the discussion on the issues presented or proposed by the two parties. The fourth round of negotiation was scheduled to begin on March $10^{\text {th }}$ to $14^{\text {th }} 2014$ in Brussels but has not taken place due to the complexity of the previous negotiations.

\section{Economic and political background of TTIP}

The Transatlantic Trade and Investment Partnership negotiations in amenities are mainly grouped into two major political and economic issues (Fontagné, Gourdon, and Jean, 2013). The first point is on international dimensions which base its argument whether TTIP is genuinely free trade agreement or not. The other issue is the greatness of the internal political forces related to TTIP, for example, the questions may include: what the economic analysis is capable of revealing on issues relating to strengths and weaknesses of domestic political funding for TTIP. These two issues make it hard for one to understand and the TTIP and support or disagree with it.

The first issue of whether TTIP is genuinely free trade agreement or not is an important area of consideration when one looks at the geopolitical background of the TTIP. Most of the consultations on services focus on the regulations and therefore requires a lot of trust between the two partners. One can reasonably say that the level of confidence can get to a perfect degree only if both partners share a similar geopolitical approach, which is they both have the same thing in mind (Cerutti, 2008). The existence of geopolitics in the US and EU PTAs has been in existence for a longer duration of time, but petite attention has been paid to it since the two negotiating mediums were in real terms and operating well. There are two distinct features of the PTAs. The first feature is on the economic impacts on the US and EU economies which are in small number due to the small economies of their partners.

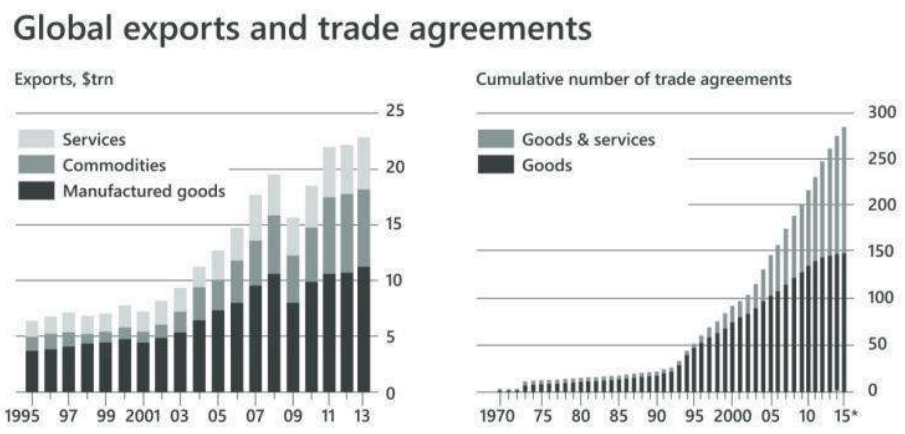

Figure 1: Global exports and trade agreements

Source: Own illustration according to UNCTAD, WTO

Figure 1 shows politial and economical background of TTIP (Aichele, Felbermayr and Heiland, 2014).

Another characteristic is that the United States and European Union uses PTAs mainly to shore up the most needed but politically hurting domestic reforms, which are the best illustration of the Korean government willingness to accept liberalization of one of the film souk in her state. None of these two features apply to the TTIP case. Therefore, the transatlantic trade and investment partnership tend to reduce charges and lower the regulatory obstacles that are currently related to the exchanges between the US and EU states. In some circumstances, TTIP has been seen to be having some controversial from the beginning. Some of the non- governmental organizations are always concerned about the lowered health and the environmental conditions, economist's argument on whether there will be any significant impact on the employment and GDP growth or not.

The forum which features the contributions of the speakers at the 2015 inter economics conference produces a balanced summary of both the anticipated benefits and the negative impacts as well to the potentially considerable trade agreements (Ingco, 2003). Another major political issue is on the domestic support for TTIP. Transatlantic trade and investment 
partnership requires strong local support for it to be successful. The estimates of TTIP costs and benefits as presented by calculable general equilibrium models can be seen clearly if adequately interpreted. Therefore, the main reason under TTIP is on the unnecessary costs of technical barriers to trade, sanitary and phytosanitary obstacles and feed regulatory instruments and many other regulatory barriers present in goods and services markets. The partnership mainly aims at preventing new excessively costly obstructions from arising where possible. TTIP is supposed to become one of the most excellent trade agreements but instead, there are some issues which are neither unique nor new to TTIP that makes it delay in becoming a superb partnership.

In TTIP, the top officials such as the presidents, the prime ministers, and other supreme leaders do not mind about the TTIP processes and procedures. They pay little attention to whether there is any gain from an agreement trade program from agriculture products, manufacturing, and facilities (Rodrik, 2004). They are instead, interested in the expected impacts of the negotiation of the entire economy of their states. It is because almost every leader in authority views trade talk just as an instrument that can enhance economic growth of their countries. The supreme leaders and the policy makers mainly tend to care about the individuals only in times of crisis such as health status, big sectorial blows, a highly noticeable domestic entrusted interest that appears in all cases and are most likely to happen in all the manufacturing and agricultural sectors. It is the time when every personal in authority will be seen to be showing many concerns, interests and care.

\section{Forecasts of TTIP and proposed benefits}

The predictions and proposed benefits of TTIP can be seen through CEPR studies which foresee almost the same various degree of liberation such as tariffs slashes focusing on goods, reduction of the non-tariff measures that covers products and services, a complete liberalization that combines both the tax cuts and the reduction of non-tariff actions and dealings. Such liberalizations have become subjects to many restrictions, for example, the first two are especially important in cases of services (Francois and Hoekman, 2010). It is because, firstly, the mentioned estimates do not take into account of foreign direct speculation flows openly. The evaluations which are major channels of most of the global competition in many services are explained in CEPR. Secondly, the liberalization aggregates each and every economic activity into small portions of sectors.

Such aggregation process may lead to a moderate level of protection by different sectors. Through construction, liberalization may underrate the significant welfare gains to be anticipated in most of the highly protected area. This is due to the relatively open activities that has been over-represented as compared to the business in extremely secured events (Dicken, 2003). Results from CEPII are similar to those of CEPR studies and can be revised as follows:

1. Profits from a comprehensive TTIP contracts which comprises of tariff cuts, services, and reduction in non-tariff measures in goods remained limited.

2. A Large percentage of the gains comes from the knowledge of non-tariff measures in products.

3. Profits from the reduction of non-tariff measures in services only are slight.

4. Goods are more traded through borders than services.

Before one dwells on the impacts on top policy makers, one should consider the size of the services sectors, and the results are supposed to be described in details to prevent questions from being raised after the exhibition. In CEPR studies, improvements from trade are the purpose of two important variables that is: the original size of the trade flows and the initial level of security. Across borders, trade has never been the primary network of global competition in amenities and therefore one should be cautious before concluding that trade does not perform well. In short, CEPR studies discriminate the developments from an open view of US and EU facilities segments to a point that the two partners are unable to capture the flow of their goods as well as their services.

The UK is one of the European Union member states which expect to improvement expressively from the settlement of the

TTIP. CEPR study was appointed by the United Kingdom's Department for Business Innovation and Skills in March 2013 (Hannon, 2016). The study suggests that most of the impacts such as shares for GDP, of the TTIP are similar for both the United Kingdom and the United States economies. For the European Union, the study shows that the relative gains would be almost twice that of GDP with about 0.4 to $0.8 \%$. The difference in the size of the FTA's possible impacts on both the United Kingdom and the United States is clearly explained through the gap in the two's primary level of honesty with the United States.

\begin{tabular}{|c|c|c|c|}
\hline \multicolumn{2}{|c|}{ EU traffis by product groups } & \multicolumn{2}{|c|}{ EU traffis by product groups } \\
\hline Product groups & $\begin{array}{l}\text { MFN applied duties } \\
\text { (average, in } \\
\% \text {, for 2012) }\end{array}$ & Product groups & $\begin{array}{l}\text { MFN applied duties } \\
\text { (average, in \%, for } \\
\text { 2012) }\end{array}$ \\
\hline Dairy products & 52.9 & Dairy products & 19.9 \\
\hline
\end{tabular}




$\begin{array}{cccc}\text { Sugars and confectionary } & 32.1 & \text { Sugars and confectionary } & 14.4 \\ \text { Animal products } & 20.4 & \text { Beverages \& tobacco } & 14.0 \\ \text { Beverages \& tobacco } & 19.9 & \text { Clothing } & 11.6 \\ \text { Cereals \& preparations } & 17.1 & \text { Textiles } & 7.9 \\ \text { Fish \& fish products } & 11.8 & \text { Oilseed, fats \& oils } & 4.84 .7 \\ \text { Clothing } & 11.5 & \text { Fruit, vegetables and plants }\end{array}$

Figure 2: Proposed benefits of $U S$ and EU tariffs by product groups Source:

Own illustration according to Bendini and de Micco, 2014

Figure 2 explains the proposed benefits of US and EU tariffs by product groups (Bendini and de Micco, 2014).

Four great scenarios are envisioned in the CEPR study. They include: Eliminating customs tariffs or several reductions in the non-tariff measures. Every situation is projected to produce significant, positive improvements for the United Kingdom on which the state income and GDP is supposed to increase from 4 to 10 million yearly that is 5 and 12.5 billion in the EU. This idea was about the extent on which non-tariff measures has been reduced. The gains that will be seen by EU as a result of removing the tariffs would be very high as compared to that of UK because of its lower initial barriers. CEPR study also shows the social impacts which stimulate the effects of transferring labor between the workers in different sectors and wage differences for both small and high quality and skilled workers. The free trade agreement does not deliver all the employment effects. Instead, they assume their perfect equilibrium among supply and labor. With the increase in production, more workers are employed due to a high demand for labor in various sectors which leads to higher wages. If the salary increase follows an active progressive graph where there are only profits, then there would be an increase in employment. The report also analyses the modeling, the assumptions, and findings of each and every analysis on the potential impacts of the European Union. These results are in two groups. The first group consists of two reports which work methodologies and assumptions differently with CEPR. The second group consists of satellite studies since they only represent the various applications of critical CEPR report on what the commission is based. According to the study, TTIP is an opportunity to raise the global standards. It might come as a result of combining GDP of not more than $\$ 30$ trillion, which will make the sheer transatlantic size more outstanding as compared to other partnership. Through this process, most of the countries under TTIP will compete to get the set standard. The study also advocates that the European Union and the United States are supposed to establish a very last bar in various sectors to cultivate the digital economy and the opposing trade and speculation protection. Transatlantic Trade and Investment Partnership have one major goal in their negotiations which is to tackle all the regulatory obstacles to trade. All the companies selling their products must, therefore, comply with both the two states rules and regulations whether they are similar or not. Other related goals of transatlantic trade and investment partnership are to eliminate tariffs, open up services, stock, and procurement. The TTIP also promote controlling cooperation to ensure there are high levels of health, safety and protection as well as environmental protection while cutting unnecessary costs.

\section{TTIP Nowadays}

The main aim of TTIP negotiations is to provide jobs and boost growth on both sides of the two partners. This goal is achievable by removing all the trade barriers. Eliminating trade obstacles would increase and simplify the process of buying and selling of all goods and services and also improve investment in each and every economy. The TTIP negotiation has three major elements which include:

1. Market access which consists of removing customs responsibilities on goods and services restrictions, gaining improved access to open markets and making it easier for clients to invest.

2. Improved cooperation in matters related to the setting of international standards.

3. Enhanced regulatory coherence and collaboration through dismantling unnecessary regulatory obstacles like the bureaucratic duplication.

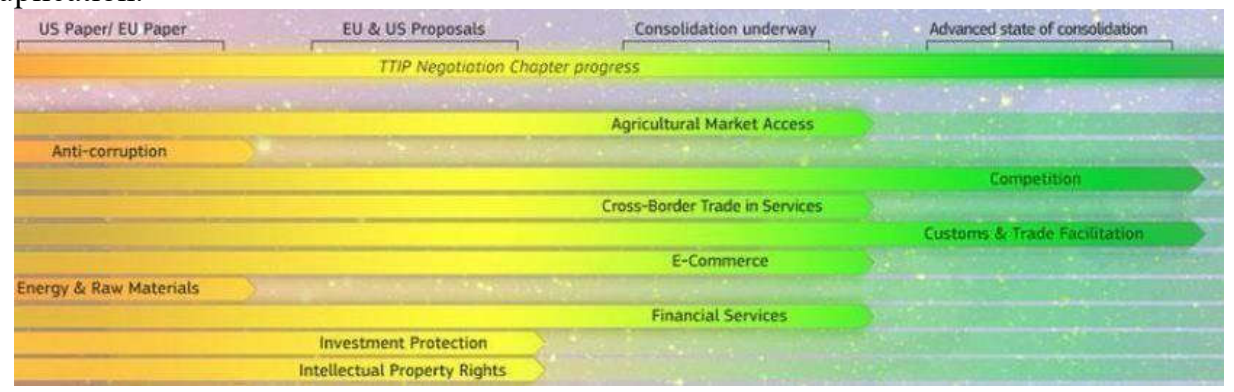

Figure 3: TTIP tent in the recent years

Source: Borghi, Helg, and Tajoli, 2014

Figure 3 shows TTIP tent in the recent years (Borghi, Helg, and Tajoli, 2014). 
Their various points to be discussed in TTIP planned agreement, for example, the EU economy which could grow by $€$ 119 billion annually. Such amount of money is equivalent to almost $€ 500$ of an average household. The TTIP, in this case, can be seen as a growth package except using taxpayers' money. Another area of interest is on the European companies which are efficient in their field of services. There is good access in the United States market by the European countries due to the environmental services and different sectors of management consultancy which creates lots of profit to them (Slack, Chambers, and Johnston, 2010). It is also one of the reasons why EU negotiators use trade consultations to enable them to open up the United States services and markets to their companies. Due to EU significant investments in the US which sum up to $€ 1.6$ trillion, they make sure their investments receive maximum protection. The US and EU agreed to include different measures in the agreement to enable small markets to benefit from it like any other big market.

The primary element in TTIP, nowadays' negotiations, consists of different norms and standards which are frequently useable in every market. The regulatory arrangement of the rules and regulations reduces the cost enforced on EU cars by $25 \%$. The agreements being discussed by the TTIP includes: boosting trade and maintain principles on the environmental and social protection, the guarantee that various foodstuffs and beverages from EU. They are the only products being sold in the United States. The possibility for EU markets to sold raw materials and energy from the US and lastly the guarantee that the country will treat public corporations like any other company are also discussed. When one looks at status quo of the TTIP, one can conclude that TTIP believes that increasing trade ties with the EU will benefit both American and European workers though the rules matter in every trade agreement. The two partners, EU and US have advanced markets, extreme national incomes and well-developed permitted and regulatory rules that are designed mainly to defend the worker's rights and protect the environment. The European nations' social program aims at protecting families and environment, and it's working excellently than the US rules and regulations. In 2012, the United States had \$107 billion shortage in trading goods with the European Union (Mann, 2012). If the two states agree on increasing employment and each and every family well-being, then the TTIP can affect trade by increasing net exports through the creation of job opportunities in the United States.

However, current reports show that despite glowing predictions by the United States International Trade Commission and various open trade advocates for job and export growth, promised advantages from NAFTA- style trade negotiations failed to pan out. The ongoing debates are about NAFTA, whether the TTIP should abandon the company driven model and adopt an entirely different approach that can benefit both partners and provide jobs opportunities for the citizens of each state. Therefore it is important for U.S and EU negotiations to dwell on employment provision and demand-led growth. The two trade negotiators should take their time to differentiate activities which will benefit the economy through supporting U.S jobs provision, domestic growth, family welfares and economic equity and the various activities that benefit the shareholders' value in different companies. Some of the things TTIP considers are the investment, Business progress, regulations protecting all working families.

Trade negotiations of TTIP have different sessions on many occasions. In July, the trade negotiators from US and EU presented a draft text that has brackets of very sensitive matters in the Transatlantic Trade and investment partnership. The selection was announced by the Chief negotiator of the European Union and his colleague in Brussels. The negotiations were pushed to the following week when the two complicated issues were presented. The two topics were public Finding and geographical indications, both of which were proposals from the two sides, US and EU states. Another negotiation was conducted after some weeks which dwelt on two important topics of the Mega-trade contract known as regulatory cooperation in manufacturing and services and also investor-state dispute settlement device. The two partners did not come to an agreement, and this led to criticism. The EU parliament, therefore, held a public consultation which was to calm the critics (Boucher, 2009). As a result, many opinions arose from the opposing team on adverse impacts of the issue being addressed.

Support for the transatlantic trade and investment partnership is always small according to one of the German NGOs who were holding a workshop for two days on TTIP. The organization has so far collected 3 milion signatures against trade deal and gathered a quarter of a million individuals to protest against it. Some of the activists and NGOs from countries such as US Public Citizen were not contented with the open stakeholder meetings, and they also hold their rally's to protest against it. During the 12th round, around 30 Greenpeace protesters chained themselves to the arrival of the discussion venue protesting the transatlantic trade and investment partnership while the US activists laid out their ambitions and desires for an acceptable trade list at the stakeholder meeting. The agendas included focusing more facilitating the overview of low-cost biosimilar drugs with free source know-how. Also the competitive supplies, directive research exceptions for copyrights and implement and ratify any of the treaties that have been agreed. The Marrakesh Treaty on worldwide access to copyright resources for visually impaired persons is one of the examples.

\section{Activism against TTIP}

Many people across Europe have taken an incredible stand against TTIP. Last year, over 3,263,920 individuals signed the petition against TTIP. In the UK the average number of people who signed against it was almost 500,000 and according to reports, more people are still signing. The main reason for protesting against TTIP is because the transatlantic trade and investment partnership has many problems such as: investor-state dispute settlement, rules and regulations which create a threat to democracy and the legal norms of the law. Such activism are there to prevent lowering of standards related to employment, privacy, social, environmental and consumer protection as well as the deregulation of public services and cultural assets that takes place in close negotiation. 
Some of the parties against TTIP include the midsized enterprises of Austria who refused to agree with the EU commissions since they believe that it's the SMEs enterprises which will benefit from transatlantic trade and investment partnership. The Midsized Enterprises believe that the Small and mid-sized enterprises will go at a loss if the opening of the domestic markets to the multinational corporations proceeds (De Beule and Van Den, 2010). Almost three- quarters of Austria's economy do not work with transatlantic trade and investment partnership. Therefore, the trade between EU and USA has very negative impacts on the economy of Austria.

Other organization that challenges the working condition of TTIP includes the AFL-CIO organization. It challenges the false statistics and fake arguments that are the only smokescreen for the anti-family agenda and puts profits ahead of any job safety, healthy food and clean water and air. As from the voice of the American protestors and workers, the AFLCIO decided to follow all the developments in the United States and the European Union negotiation carefully (Mazur, 2000). Through this act, the o-organization will be unable to support and trade consultation unless it balanced, it protects the rights and individual interest as well as their family well-being, it creates job opportunities and also promotes a healthy and perfect environment for the citizens. Therefore for transatlantic trade investment and partnership to operate well, all the business arguments should be enforced fairly in an open discussion and should be quickly and consistent. The TTIP should consider doing so to support the American workers who struggle for their country, but the wealth only goes to the hands of the $1 \%$ who are mainly the stakeholders and those in high ranks.

\begin{tabular}{|c|c|c|c|}
\hline Organisation & Country & Organisation & Country \\
\hline 38 Degrees & UK & $\begin{array}{c}\text { Bürgerinitiative Frackingfreies } \\
\text { Hamburg (BI-FFH) }\end{array}$ & Germany \\
\hline A-BAL-Balpárt & Hungary & $\begin{array}{l}\text { Bürgerinitiative } \\
\text { Frackingfreies Hessen }\end{array}$ & Germany \\
\hline Academia Cidada & Portugal & $\begin{array}{l}\text { Bürgerinitiative gegen } \\
\text { CO2-Endlacer e.V. }\end{array}$ & Germany \\
\hline $\begin{array}{l}\text { Action Solidarité Tiers Monde } \\
\text { (ASTM) }\end{array}$ & $\begin{array}{l}\text { Luxem- } \\
\text { bourg }\end{array}$ & $\begin{array}{l}\text { Bürgerinitiative gegen } \\
\text { Gasbohren Kleve }\end{array}$ & Germany \\
\hline Active Watch & Romania & $\begin{array}{l}\text { Bürgerinitiative Havixbeck } \\
\text { zur EBI "Stop TTIP" }\end{array}$ & Germany \\
\hline Afri & Ireland & $\begin{array}{c}\text { Bürgerinitiative Lebenswerter } \\
\text { Heistergau }\end{array}$ & Germany \\
\hline AIETEC & France & $\begin{array}{l}\text { Bürgerinitiative } \\
\text { Lebenswertes Korbach }\end{array}$ & Germany \\
\hline $\begin{array}{l}\text { action ./. arbeitsunrecht e.V. - } \\
\text { Initiative für Demokratie in } \\
\text { Wirtschaft und Betrieb }\end{array}$ & Germany & Bürgerinitiative Politik 21 & Germany \\
\hline $\begin{array}{l}\text { Aktionsgemeinschaft } \\
\text { Artenschutz }\end{array}$ & Germany & Bürgerinitiative Würzacher Becken & Germany \\
\hline $\begin{array}{l}\text { Alternative und Grüne } \\
\text { Gewerkschafterinnen }\end{array}$ & Austria & BUND & Germany \\
\hline Amigos de la Tierra Espana & Spain & $\begin{array}{l}\text { Bundesverband Bürgerinitiativen } \\
\text { Umweltschutz }\end{array}$ & Germany \\
\hline $\begin{array}{l}\text { Arbeitsgemeinschaft } \\
\text { Bäuerliche Landwirtschaft }\end{array}$ & Germany & $\begin{array}{l}\text { Bundesverband Deutscher } \\
\text { Milchviehhalter e. V. } \\
\text { Bundesverband Naturkost } \\
\text { Naturwaren }\end{array}$ & $\begin{array}{l}\text { Germany } \\
\text { Germany }\end{array}$ \\
\hline
\end{tabular}

Figure 4: Organisations and parties against TTIP

Source: Own illustration according to Esty, 2007

Figure 4 explains the organisations and parties against TTIP (Esty, 2007).

\section{Criticism to TTIP}

There are so many reasons why TTIP should put an end to its paths. Different critics points at the central gap between the interest of the company and the interest of the customer due to the secret negotiation being done in Brussels. Some of the criticism includes: investment protection, impact on national life, transparency, financial regulation and adverse economic consequences. Under investment protection, the most concerned aspect of TTIP is the Investor- state Dispute settlement mechanism that can be built into an agreement (Gagné, and Morin, 2006). The arrangement gives different companies the capacity to take authorized actions against conditions that they notice to be hindering the potential profits. This mechanism enables all corporations investing in Europe to have the power of challenging EU governments directly whenever they observe changes in the law in the sector of public health, customer's environmental and social protection. Criticism on impacts of national life is mainly concerns with the powers that might jeopardize the federal laws and regulations. It looks at what the company's and deregulation rights could mean to the gradual transfer of the United Kingdom National Health Service. The ISDS is one of the reasons why TTIP has been negatively viewed.it is because of its continuous trials to bring health back to the public ownership it was before and faced barriers from the TTIP several times. GMOs are one of the strong opposition in foodstuffs because of TTIP deregulation. These deregulations are the recent EU restrictions on GMOs that European public has made clear, and it will not accept any of its food supply. The French minister of foreign trade once said that the country where mobilization against transatlantic treaty is strongest is French. His primary concern was on the future of the local French cheese and milk production areas.

Criticism on transparency is mainly concerned with the nature of the TTIP deliberations. Many issues arise in the negotiation table by the public thinking that they will be discussed by the commissions yet in the real sense, these issues 
are never tackled. The negotiations are always carried out in secret meetings held between US and EU commission. One can, therefore, conclude that TTIP is driven by a corporate agenda at the expense of the customer and public life (Leys, 2003). Another criticism is on the financial regulation. Many critics' points to the transatlantic trade and investment partnership with a dull financial sector that is far from needed control. One of the reports explains that most of the critics fear that package contract might force businesses in regulatory ethics at the expense of financial steadiness. They fear that TTIP might result in rolling back of financial regulations done under an act.

The adverse Economic impact is mainly concerned with the promise made by EU Commission that transatlantic trade and Investment Company would create job opportunities to its citizen. The major criticism is the uncertainty of employment instability and economic growth in US and EU. The S2B network reads a net loss of 879,289 after the implementation of NAFTA and economic restructuring that led to unemployment. All these negative impacts are as a result of the implementation of TTIP.

\section{Conclusion and summary}

In conclusion, TTIP's strengths and weaknesses can be identified through critical appraisal. Some of the shortcomings of TTIP include: Overstated Economic Benefits, Anti-competitive rules of origin, the dispute settlement problem, Exclusions of China and other countries, Contradictory American moves, Small benefits with great harm. Excessive Economic Benefits applies to both the predictable effects on the economic growth as well as the predicted jobs creation. The essential reason for the adverse repercussions on the agreements should be taken into consideration. Anticompetitive rules of origins are also one of the main TTIP's weaknesses. Preferential trade agreement tends to facilitate commerce among the participating economies which do not liberalize the entire external trade of the affected countries. One can conclude that the countries want to prevent their foreign trade policy from being undermined. Rule of origin, therefore, serve to explain the product's nationality.

Another weakness is on the exclusion of China Republic and other different states. Overestimated economy is one of the questions being asked to the TTIP. There is an assumption that China Republic is willing to accept rules and regulations from the preparation it has been excluded. Dispute settlement problem is another concern affecting TTIP. The United States and the European Union have often received complaints in their work frames such as disputes over Airbus and Boeing. Contradictory American moves are also one of the TTIP weaknesses. The US financial reports have been heading in the opposite direction. One of the reports stated that Washington left the home country under which the Deutsches and many other banks were being operated (Babb, 2013). Washington did not evaluate the risk of assessment models used by various foreign banks.

Small and medium-sized enterprises characterize all businesses in European Union by $99 \%$. Different factors determines whether an initiative is an SME or not and they include: Staff headcount and turnover or balance from the total balance sheet. There are two main types of potential benefits for SMEs enterprises if they meet the criteria.

1. The suitability for support under different EU corporate support programs that targets SMEs mainly. An example of such programs is the research finding and competitiveness and innovation funding which might be banned as biased government assistance.

2. Reduced fees or fewer requirements for the European Union administrative compliance.

Monitoring the implementation of SME definition on a regular basis by the commission enable one to understand the application of various rules in the existing endorsement through the provision of guidance or updating editions of SME definition User Guide (FRAMEWORK, 2016). Figure 5 shows the monitoring of implementation of SME defination. There are some reasons why EU should treat TTIP with care. These reasons can be summarized in point forms as follows: Products from TTIP are brought to the market cheaper and faster, doing business has been made much easier. The extreme standard levels are promoted and harmonized, innovation and creativity are stimulated, raw materials and energy markets are rebalanced, there is a broad range of choices of services, investment is supported and encouraged, and lastly public contact opportunities are made accessible to all individuals.

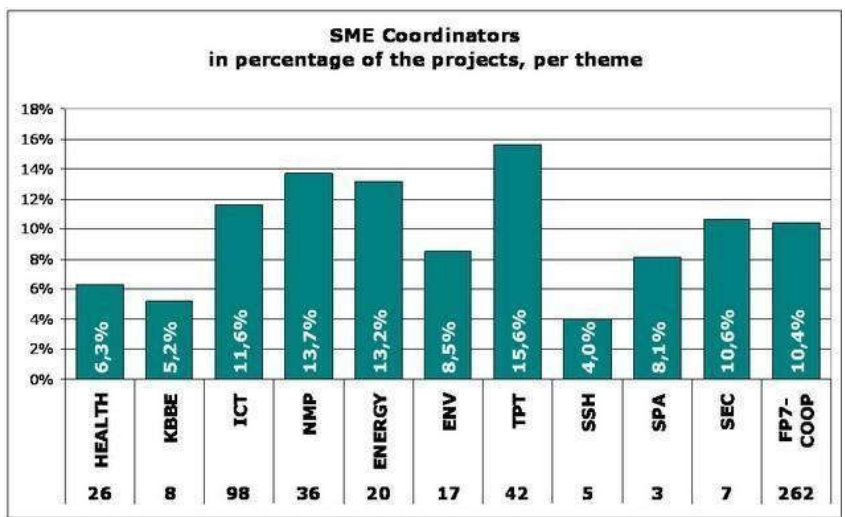


Figure 5: Monitoring of implementation of SME defination Source: Fabri, 2014

In summary, despite the challenges and critic facing transatlantic trade investment and partnership, it's one of the most globally recognized companies that create job opportunities in various countries they operate. TTIP disadvantages or weaknesses overdo the strengths, but it still has more clients who want to work with them. Therefore, one can conclude that TTIP is the best partnership worldwide which cater for each and every individual need in as much as the stakeholders do not play their roles as needed.

\section{Literatures}

[1].Abrahamson, P. and City, G., 2008. European Union influence on Central American integration: the case of the coming association agreement.

[2].Aichele, R., Felbermayr, G.J. and Heiland, I., 2014. Going deep: The trade and welfare effects of TTIP.

[3].Alter, K.J. and Meunier, S., 2006. Nested and overlapping regimes in the transatlantic banana trade dispute. Journal of European Public Policy, 13(3), pp.362-382.

[4].Babb, S., 2013. The Washington consensus as transnational policy paradigm: its origins, trajectory, and likely successor. Review of International Political Economy, 20(2), pp.268-297.

[5].Bendini, R. and de Micco, P., 2014. The expected impact of the TTIP on EU Member States and selected third countries. Directorate-General For External Policies Policy Department, European Parliament.

[6].Borghi, E., Helg, R. and Tajoli, L., 2014, December. Trade effects of the Transatlantic trade and investment partnership. In Conference on the European Parliament in external trade and investment policy: five years after the Lisbon Treaty.

[7].Boucher, S., 2009. If citizens have a voice, who's listening? Lessons from recent citizen consultation experiment for the European Union.

[8].Cerutti, F., 2008. Why political identity and legitimacy matter in the European Union. The search for a European identity: values, policies, and legitimacy of the European Union, pp.3-22.

[9].Cottier, T., 2006. From progressive liberalization to progressive regulation in WTO law. Journal of International Economic Law, 9(4), pp.779-821.

[10]. De Beule, F. and Van Den Bulcke, D., 2010. Changing policy regimes in outward foreign direct investment: from control to promotion. In Foreign Direct Investments from Emerging Markets (pp. 277-304). Palgrave Macmillan US.

[11]. Dicken, P., 2003. Global Shift: Reshaping the global economic map in the 21 st century. Sage.

[12]. Esty, D.C., 2007. Good governance at the world trade organization: Building a foundation of administrative law. Journal of International Economic Law, 10(3), pp.509- 527.

[13]. Fabri, A., 2014. Occasional Papers on Islands and Small States.

[14]. Fontagné, L., Gourdon, J. and Jean, S., 2013. Transatlantic trade: Whither partnership, which economic consequences. CEPII Policy Brief, 1.

[15]. FRAMEWORK, A.N.M.A., 2016. In the Spotlight.

[16]. Francois, J. and Hoekman, B., 2010. Services trade and policy. Journal of Economic Literature, pp.642-692.

[17]. Gagné, G. and Morin, J.F., 2006. The evolving American policy on investment protection: evidence from recent FTAs and the 2004 model BIT. Journal of International Economic Law, 9(2), pp.357-382.

[18]. Hannon, E., 2016. Industrial policy and employment in the UK: evidence from the pharmaceutical sector. Industrial Relations Journal.

[19]. Hoekman, B.M. and Kostecki, M.M., 2009. The political economy of the world trading system. OUP Oxford.

[20]. Ingco, M.D., 2003. Agriculture, trade, and the WTO: Creating a Trading environment for development. Washington, DC: World Bank.

[21]. Khanna, T., Palepu, K.G. and Sinha, J., 2005. Strategies that fit emerging markets. Harvard business review, 83(6), pp.4-19.

[22]. Leys, C., 2003. Market-driven Politics: Neoliberal democracy and the public interest. Verso.

[23]. Mann, M., 2012. The sources of social power: Volume 3, global empires and Revolution, 1890-1945 (Vol. 3). Cambridge University Press.

[24]. Mazur, J., 2000. Labor's new internationalism. FOREIGN AFFAIRS-NEW YORK-, 79(1), pp.79-93. Rodrik, D., 2004. Industrial policy for the twenty-first century.

[25]. Slack, N., Chambers, S. and Johnston, R., 2010. Operations management. Pearson Education. Smith, K.E., 2013. The European Union foreign policy in a changing world. John Wiley \& Sons. 